\title{
The Feminist Film: An Analysis of the Feminist Narrative Form in the Films of Rakshane Bani-Etemad, Pouran Derakshande, and Manijeh Hekmat
}

\author{
Miniature Malekpour ${ }^{1}$ \\ ${ }^{1}$ Ph.D. Candidate, the Australian National University, Canberra, Australia.
}

\begin{tabular}{|c|c|}
\hline Article Info & Abstract \\
\hline $\begin{array}{l}\text { Article history: } \\
\text { Received: 09 August } 2020 \\
\text { Revised: } 28 \text { September } 2020 \\
\text { Accepted: 09 October } 2020\end{array}$ & $\begin{array}{l}\text { Purpose: In this paper, the aim is to examine film form and narrative in } \\
\text { relation to gender identity and the politics of representation. Drawing } \\
\text { distinctions between these methods make it possible to identify how feminist } \\
\text { frameworks are used to examine identity, aesthetics, and ideology through } \\
\text { film culture. }\end{array}$ \\
\hline $\begin{array}{l}\text { Keywords: } \\
\text { Feminism, } \\
\text { Middle East, } \\
\text { Iranian Cinema, } \\
\text { Women Directors, } \\
\text { Gender Studies }\end{array}$ & $\begin{array}{l}\text { Approach/Methodology/Design: Thematic analysis, employing a feminist } \\
\text { perspective. Three films were selected for conducting this type of analysis: } \\
\text { Rakshane Bani-Etemad's Nargess', Manijeh Hekmat's 'Women's Prison' } \\
\text { and Pouran Derakshande's 'Hush! Girls Don't Scream. } \\
\text { Findings: By understanding the representation of women in Iranian Cinema } \\
\text { and the cultural/traditional norms and values of the Iranian Society, I argue } \\
\text { that the narrative form identifies feminist perspectives, which create an } \\
\text { Iranian feminist cinema. Combining textual analysis with a greater concern } \\
\text { for the audience-text relationship, and the rejection of the male gaze, these } \\
\text { films recognize texts as shaped by the struggle to make meaning amongst }\end{array}$ \\
\hline $\begin{array}{l}\text { Paper Type: } \\
\text { Research Article }\end{array}$ & $\begin{array}{l}\text { institutions which shapes the filmic text from different components of the } \\
\text { socio-historical context, and which creates a relationship between feminist } \\
\text { film and cultural studies. }\end{array}$ \\
\hline $\begin{array}{l}\text { Corresponding Author: } \\
\text { Miniature Malekpou }\end{array}$ & $\begin{array}{l}\text { Practical Implications: Iranian female directors have been adopting a } \\
\text { feminist approach in their films' narrative structure dating back to the } \\
\text { reformist period of the } 90 \text { s. Through the social/political context of female } \\
\text { characters and the counter-cinematic development of agents, circumstances, }\end{array}$ \\
\hline $\begin{array}{l}\text { Email: } \\
\text { Miniature.malekpour@anu.edu.au }\end{array}$ & $\begin{array}{l}\text { and surroundings of the systems of patriarchy and oppression, women } \\
\text { directors have been applying feminist narrative form to their work as evident } \\
\text { in Rakshane Bani-Etemad's 'Nargess,' Manijeh Hekmat's 'Women's Prison' } \\
\text { and Pouran Derakshande's 'Hush! Girls Don't Scream. } \\
\text { Originality/value: This paper analyzes the principles offemale desire through } \\
\text { these selected films, the patriarchal dominance of societal oppression, the } \\
\text { female condition, and the examination of violence in the traditions and } \\
\text { attitudes related to women while looking at the representation of this violence } \\
\text { and oppression in the Iranian Society. }\end{array}$ \\
\hline
\end{tabular}

\section{Introduction}

Through connections between three dimensions of narrative cinema, story world, plot structure and narration, female Iranian filmmakers have presented feminist cinematic language that is balanced between narrative and stylistic elements. Based on theoretical models which provide a characteristic conceptualization of 'women's thought', narrative development determines how form and style participate in the spectator's experience. The events of Rakshane Bani- Etemad's 
Nargess, Manijeh Hekmat's Women's Prison, and Pouran Derakhshande's Hush! Girls Don't Scream are directly presented to us in the plots of the films.

The feminist theoretical models that are presented guide the way these films' directors construct and shape gender identity in the form of self-reflection, the relationship between the dialogue of parler femme ${ }^{1}$ and desire, feminine spectatorship and freedom, and how women are represented as active or passive characters in lieu of applying a feminist critical lens. This paper is divided into sections on the social/political context of the female character/protagonist; and the counter-cinematic development of the agents, circumstances, and surroundings of the systems of patriarchy and oppression. These feminist frameworks are used to examine identity, aesthetics, and the ideology of Iranian film culture. The questions raised about the subtext of these three-dimensional feminist frameworks include whether the female spectator identifies with the female protagonist. If so, what kind of gratification is obtained through such identification? What are the temporal relationships between the events in a story that occur within a social/political context? Are the directors' films 'feminist'? How are the female protagonists oppressed by the patriarchal social system?

The approach towards narrative film can be broken down into five sub-categories to help identify the feminist position assumed in thecorpus of the selected films: film form, narrative, film genre, the identity and politics of representation, and stereotypes and national identity (Nelmes, 2012). In this paper, it is better to examine film form and narrative in relation to gender identity and the politics of representation. Drawing distinctions between these methods make it possible to identify how feminist frameworks are used to examine identity, aesthetics, and ideology through film culture.

\section{Analysis and Discussion}

\section{Film Form and Narrative}

The significance of 'film form' is related to the overall relationships between the key elements of a film within its milieu. These elements, like feeling and meaning, interact with one another, eliciting an emotional response from the spectator. The emotion depicted in the text exists in parallel to the emotional response of the spectator. Dismissing previous feminist film theories, especially the psychoanalytic theories of Laura Mulvey's male gaze and phallocentric pleasure in favor of reading films as cultural texts changes the dynamic of the film narrative. By rejecting earlier positions on women's cinema, which include Claire Johnston's stance on women's cinema, which disregard sociological analysis of women in cinema and any realist stance, the relationship between the feminist film and cultural studies becomes a tool of resistance for Iranian female directors. Patricia White (2014) argues that the previous approaches had significant consequences for feminist film studies. She suggested that Johnston's women cinema, although still a projection, created a sense of false consciousness (White, 2014). She goes on to project that Teresa de Lauretis's 'reframed debates around

\footnotetext{
1 'Parler femme' first appeared in Luce Irigary's 'This Sex Which Is Not One'.
} 
women's cinema' held its own aesthetically and politically in opposition (White, 2014). In the Technologies of Gender, De Lauretis(1987) articulates that due to the nature of feminism's historical condition of existence being the product of 'critical negativity' of theory and 'affirmative positivity' of its politics. By defining the subject of feminism as not only as formal codes and content but as a vehicle which addresses the spectator's socio-political dialect, as well as inscribing gender subjectivity on screen, which becomes a major force in analyzing Iranian films made after the reformist period (1997-present). Cinema becomes a social technology sphere rather than focusing on the artist behind the camera and the gaze (White, 2014).

\section{Gender Identity and the Politics of Representation}

The gender identities and politics of representation of female characters, as seen through the critical lens of feminist filmmakers like Bani-Etemad, Hekmat, and Derakhshande are reflected in strong protagonists and agents. The audience is either meant to sympathize with them, as in the case of Afagh in Nargess; view them as people who embody a value system that is opposed to the 'role of the woman as a system of value' within a patriarchal society (Irigary, 1985), as in the case of Shirin in Hush! Girls Don't Scream; or recognize them as the people whose character arcs are affected the most by the events of the film, as in the case of Mitra in Women's Prison. In Nargess, there are two strong female characters and a weak male character, Adel. Both Afagh and Nargess take care of Adel to the point of controlling him. However, the narrative structure is focused more on Afagh, who has more character depth than Nargess. The actions of Afagh, a criminal who embodies impurity, immorality, and deceitfulness, augment both the positive and negative feminist attributes that elicit sympathy from the spectator. Positioning Afagh as the main protagonist of Nargess is a noteworthy choice by Bani-Etemad. She is a low-class, morally indecent protagonist who steals to survive. Her moral compass is broken, and she is deemed a renegade who does not follow the norms of 'respectability' (Dabashi, 2001). However, her distinctive character arc makes up for her lack of decorum. We gradually learn throughout the film that Afagh was abandoned by her husband, separated from her only child, and forced into a life of crime. She takes in Adel, whom she protects and loves as a child, lover, and husband. She pretends to be Adel's mother, enabling him to approach Nargess's mother to ask for her hand in marriage. Even after this self-sacrificing act, which appears to be her only redeeming one, she is abandoned, as Adel leaves her for Nargess, the 'ideal' woman. Her narrative agon ${ }^{2}$ clearly surpasses that of either Nargess or Adel.

Manijeh Hekmat's Women's Prison focuses our attention on the actions and reactions of the two central female characters, the protagonist, Mitra, a convicted murderer, and the antagonist, Tahereh, a hardened prison warden. In a film with a virtually all-female cast, no other characters receive as much screen time as this duo. Mitra and Tahereh are opposites, yet they are both oppressed in their own fashion, sharing the common identity of being a woman under the heel of repression, male power, and sexual subjugation in Iran. Mitra is a rebellious figure,

\footnotetext{
2 'Agon' refers to a contest or competition.
} 
confronting Tahereh's method of discipline, resulting in constant psychological/physical torture. For example, Tahereh punishes Mitra's insubordination by having her head shaved. The existence of a gender-based hierarchy is cleverly depicted in the role of the female antagonist. Tahereh's first role as a warden is to enforce the hijab code of Islam, ensuring that the prisoners fully cover themselves; any other sort of rebellious activity is addressed equally severely. Hekmat's protagonist creates an 'ideological structure that divides two classes', not through the literal construct of 'men and women' but based on a 'hierarchical relation of domination and subordination' (Lazar, 2007). Tahereh's internal and external goals are gradually revealed as two struggles. One is the outer struggle of upholding a disciplinary campaign under oppressive circumstances, sadistic and in accordance with patriarchal grievances; the other is an inner battle, which is shown towards the end of the film when she applies confiscated lipstick to her lips and explores, for a brief moment, freedom from the beliefs with which she has imprisoned herself. This struggle connects both characters, who are imprisoned by both internal and external conflicts (Mehring, 1990). Tahereh eventually loses her power, and Mitra gains her freedom after 17 years, with both women living through a war of psychological erosion created by mechanisms of oppression.

In Darakhshande's Hush! Girls Don't Scream, the female protagonist, Shirin, embodies postfeminism, rejecting the male gaze and separating herself from the feminine by identifying with her masculine side. Shirin appears in a blood-stained wedding dress in front of her fiancé, Amir, on their wedding night, after being arrested for the murder of the building's caretaker. Through flashbacks, we learn that, when she was eight years old, Shirin was raped and abused by her mother's employee. As we examine Shirin's journey through her conscious and unconscious actions, we discover that, with the killing of the caretaker, Shirin separates herself from the feminine, rejecting the male gaze and regaining the agency she lost as a child by saving a child who symbolizes her younger self. This conscious act is a mirror of her unconscious needs and wants, defying the patriarchal silence. Both Shirin and Farima, Shirin's lawyer, share the same dramatic goal, which is, of course, her exoneration. As Farima battles to save Shirin from death row, evidence of the patriarchal silence mechanism, in this case, in relation to the rape of a female child, is poured over and over in an attempt to overflow with patriarchal dictation by excluding the valid reason for the act of murder. This patriarchal dominance is also seen in flashbacks, in which Murad, Shirin's abuser, threatens to bring shame to her family and kill her if she does not remain quiet about the abuse. When the young Shirin attempts to confide in her mother about a 'school friend' who is being abused, her mother hushes her and tells her to forget about what she has heard. Through these flashbacks and her paranoia, we glimpse the psychological and physical battles between Shirin's conscious and unconscious selves and how she is haunted by the memories of her abuse. When she becomes engaged the first time, she runs away from her family after she receives a prank call, which triggers her memories of Murad. Her second engagement also prompts her to attempt suicide by cutting her wrists on her wedding day after she sees a hallucination of Murad at the bridal store.

Unfortunately, these types of events do not only afflict Shirin, but also to the abused child she has saved, whose parents would rather protect their reputation than help Shirin in court by acknowledging their daughter's abuse and the photographs taken of her. The desire to preserve 
one's reputation runs throughout the film. Wants are prioritized over needs when we witness Amir caring most about his reputation at the start of the film, quickly trying to dismiss Shirin without inquiring about the justification for the murder. Of course, once the truth is exposed, his character's arc turns into astory of redemption, with him depicted doing everything he can to save Shirin from death row. We see this when he and Farima look for the brother of the man Shirin killed to receive a diyaa ${ }^{3}$ from the conviction qisas ${ }^{4}$.

\section{The Dialogue of Desire in Nargess}

The institutionalized principles of modesty in Iranian cinema are the result of fear within a patriarchal society that is controlled by Islamist ideologies. These principles have been created to counter the disruptive link between the 'corruptive influence of cinema on women and of women on cinema' (Naficy, 2001). After the Islamic revolution, Iran's government focused on strengthening two existing discourses to 'purify' the film industry and impose censorship based on the Islamic code of modesty.

The representation of the veil in Iranian cinema required filmmakers to depict all the spaces in the mise en scène as if they were public ones. This created an unrealistic approach, generating a distorted representation of Iranian women. For example, there were scenes in which a husband and wife were in their own home and the wife was fully veiled. Artistic misrepresentation of real life is, in fact, a representation of the reality that the Islamic regime has created. The voyeuristic nature of these scenes not only strongly contrasts with that of Western cinema but is psychologically harmful and challenging for the actors, who must portray their characters in a way which complies with the modesty codes. This is evident in older films in which the male characters are forbidden to touch actresses playing intimate relatives (Naficy, 2001). The audience was not allowed (this has changed over time) to watch family members console each other physically due to the conversion of the characters' private space into the public domain. Some films suffered heavily from this incongruous portrayal. To produce movies without the voyeuristic gaze of normative cinema, they were inscribed with a subject-spectator pose that involved the rendering of time and space 'continuous and hence realistic in dominant cinema's scopophilic and voyeuristic procedures’ (Mottahedeh, 2008).

Bani-Etemad's Nargess brought her worldwide recognition. Opposing the traditional depiction of the female protagonist, in Nargess, we witness the essence of strong female desire, something which had never been portrayed with such conviction. The boundaries pushed in this film are beautifully translated into the dialect and emotions of the female protagonist, Afagh. What was typically veiled in Iranian cinema was unveiled in her character's actions and reactions. Dismissing the no-eye-contact dictate, especially in the context of Afagh's no-

\footnotetext{
${ }^{3}$ diyaa, in Islamic law, is the financial compensation paid to the victim or his/her heirs in cases of murder, bodily harm, or property damage.

${ }^{4}$ Qisas or qișāṣ, ('accountability, following up after, pursuing, or prosecuting') is an Islamic term interpreted as 'retaliation in kind', an 'eye for an eye', or retributive justice.
} 
bullshit persona and between the characters of Adel and Nargess, the audience is introduced to the traditional practice of polygamy, which was re-introduced under the Islamic regime.

Alternatives to the male gaze were created to identify with the female spectator, including the adoption of the masochism of over-identification or the narcissistic point of view needed in the production of one's own object of desire. The female spectator and the female character were required to turn their 'active desire into a passive desire to be the desired object' (Doanne, 1987). The issues of subjectivity and desire are parallel for the female spectator, involving a process of self-fabrication within the narrative of woman-as-woman and deriving from the cinematic gaze directed at female characters. The ideological construction of the camera, character, and spectator became an important means of explaining female subjectivity, 'inscribing desire into the codes and conventions of the imagery and narrative' (Smelik, 2016). Thus, the female spectator is lured into femininity. This voyeurism, combined with the element of narcissism, functions as a sign within an 'Oedipal narrative', which suggests that a woman cannot be the subject of desire, but rather only a representation of such (De Beauvoir, 2010). This type of narrative is evident in the love triangle between the three protagonists of Nargess. The relationship between Afagh and Adel takes the shape of incestual lust, as Afagh cares for and loves Adel like her own son (Dabashi, 2001). The female spectator is not expected to identify with the male protagonist but rather with Afagh.

The experience of female spectators is identified by the dialect of desire that emerges in the movie. Regarding desire, we adopt an anti-Oedipal approach, as in Gilles Deleuze and Felix Guattari's Anti-Oedipus (1972). The concept of 'female desire' is formulated through the lens of subjectivity, while questions regarding how ethical the concept is are frequently broached ${ }^{7}$ due to the nature of the risks in relating to the desire(s) of the spectator (Ince, 2017). The notion of desire manifests itself in social systems through the economy of sexual subjectivity (Ince, 2017). Although we learn early that Afagh lost her husband to another woman, her sexuality and desire become a driving force in the narrative elements of the film, as she helps Adel win Nargess's hand in marriage, 'dismantling the patriarchal constituted roles of both men and women and the relationship of power they entail' (Dabashi, 2001). Irigary's conceptualization of women's desire suggests that women 'do not try to master the other but to give birth to themselves' (Lorraine, 1999). We can also infer that a woman's desire is not limited by her own needs but involves self-sacrifice and a lack of possessiveness, unlike that of her male counterpart. 'Unlike masculine desire, her desire does not necessarily take the form of a desire to possess a discrete entity' (Lorraine, 1999). Afagh's actions suggest that, even though her husband has left her, she does not succumb to the passive role of the self-pitying subject; instead, she arranges the union between Adel and Nargess and takes flight in her own suffering (Dabashi, 2001). The maternal enclosure depicted on screen becomes a 'non-phallic model with which to represent female desire in its own terms' (Jones, 2011).

The language of desire used throughout this movie reflects Luce Irigary: Philosophy in the Feminine and the concept of parler femme, questioning female subjectivity as it not only 'implies to psychosexual positioning, but also social positioning' (Whitford, 1991). The spectator identifies with the challenges of sexuality in Nargess through the subjective roles of 
the two strong female characters, Afagh and Nargess. The narrative agency of the older female character determines which symbolic organization of the patriarchal social order we see, as the focal point of the narrative involves women's desires and the alternative libidinal economy used for representation and sublimation through the man's death drive (Ince, 2017), in this case, Adel's submission to the entre-femme (women amongst themselves). Adel is a child-like character who fantasizes about escaping his criminal life when he is only managing to survive because of the generosity and love that he receives through Afagh's female desire (Dabashi, 2001). Even though Adel does not desire her, Afagh uses the triadic model of polygamy to control his sexuality; thus, when deconstructing the scene in which Afagh pretends to be Adel's mother to convince Nargess's family to agree to his proposal, female desire becomes the exclusive focus of the sexual differences between the female and male characters. This method exemplifies 'women's cinema as a feminist re-invention of film which reworks conventions of narrative and narration, authorship and spectacle, to create the formal conditions for inscription of female desire and points of view' (Butler, 2012).

The suicide of Afagh should not be viewed as an anti-feminist cathartic moment but rather the act of a woman who is in control of her own desire and destiny, and abandonment, even by a male, should be seen as the abandonment of the world. The last scene, in which Afagh runs into oncoming traffic on a highway, is symbolic of the ultimate female desire: freedom from a world that has abandoned her.

\section{The Socio/Political Narrative of Women's Prison}

To deconstruct the social/political context of women in Iranian film, we must first examine the patriarchal society which governs their role. Afterwards, when examining another representation of oppression in Women's Prison, a feminist film-analysis method will be applied to break down the oppressive conditions of the characters in their wider context. A semiotic framework is often applied when examining the difference between the sexuality of the cinematic text and the tenuousness of female subjectivity in the narrative structure of the film (Smelik, 1998). It is important to highlight some women's issues that have led to political/social mobility and protests. During the 1979 revolution, women were forced to wear the hijab under a compulsory rule (not yet a law) while participating in protests. This was only the beginning of the discrimination against them. The image of the woman was reconstructed after the 1979 revolution and women's socio-economic position became restricted by the ideology of the revolution. Ruhollah Khomeini's anti-Shah campaign was largely supported by women. However, these women were only situated within a family-based context and included so they would contribute to the social production of society. Any political right, including the right to vote, was believed to affect the moral status of women in society. Although this was Khomeini's point of view, in a contradictory move, the regime encouraged the participation of women in the revolutionary process. This ambivalence became the basis of an institutionalized contradiction plaguing the Islamic republic from 1979 until now. Women's participation in the 1979 revolution was not framed in terms of emancipation but rather cleared the way for women to engage actively in the public sphere. Active members of various parties, including 
communists, socialists, liberals, and Islamists, protested the monarch's policies. Women from various parties, including those who opposed Khomeini's radical views, covered up during protests, unaware of the precedent their actions were setting. These women could not have predicted that a law mandating wearing the hijab would be enacted by the regime. In February 1979, Khomeini stated that women should dress in accordance with religious guidelines. This statement divided the women's movement, which included liberal and leftist members (Moghadam, 1995). After the implementation of this law, the regime stated that compulsory veiling was necessary to prevent women from being harassed, amongst many other religious reasons. It was believed that veiled women were not only a symbol of the cultural transformation of society but a sign of morality, which was signified by control of female sexuality (Moghadam, 1995).

Veiling in the film industry became a crucial means of boycotting the Western norm of the voyeuristic subject-spectator. The religious activities which women in Iran were allowed to undertake within the public space included women-only ceremonies, family gatherings, and religious meetings and rituals. Regarding why women's sexuality was regarded as a weapon in policies within the context of social-economic problems, it can be observed that women hold vast power regarding inciting protests. The female body became institutionalized after the revolution and was suppressed and controlled under the ideology of the regime. It is important to briefly examine the historical image of the woman in Iran during the constitutional revolution between 1906-1911 ${ }^{5}$. Ironically, the reforms of the monarchy, including the modernization of its policies, which resulted in a ban on veiling, involved forcibly removing scarves from the heads of women on the streets. This 180-degree turn 70 years later may have been the result of the suppression of traditional values.

The women's movement struggled to gain traction during the 1980-1988 Iran-Iraq war or the reconstruction period between 1989-1997. The movement did not begin to enjoy any real momentum until the presidency of Mohammed Khatemi during the reformist period in 1997. This occurred thanks to the various student movements that gave life to various women's organizations. During this period, 55 NGOs were established in various social, cultural, and political fields. By the end of the reformist period, 450 women's NGOs had been established in Iran (Socai, 2013).

In Ziba Mir Hosseini's article in Negotiating the Politics of Gender in Iran, she explains that religious traditions were commonly depicted in the experiences of the women in films made in the first few decades after the 1979 revolution and that, after the reformist period, female characters were portrayed more realistically and with a feminist pose. However, Islamists continuously deny the existence of any 'women's movement', labeling women's activism and the fight for equal rights as a 'harmful feminist deviation instigated under the Western influence', casting it as a movement for 'regime change' and resulting in negative propaganda,

\footnotetext{
5 The Persian Constitutional Revolution, also known as the Constitutional Revolution of Iran, took place between 1905 and 1911. The revolution led to the establishment of a parliament in Persia during the Qajar dynasty.
} 
arrests, and imprisonments.

In Women's Prison, the toll of the patriarchal system is shown through the treatment of the characters and the depiction of their stories through prison bars, with the authoritarian regime portrayed as the jail itself. The reasons for some of the characters' imprisonment also allude to the after-effects of the revolution, with the concept of prison and imprisonment linked to institutions' control over repressive mechanisms, power, and sexuality.

As stated earlier, Women's Prison focuses on two strong female characters, the protagonist, Mitra, and the antagonist, the prison warden Tahereh. These characters challenge each other throughout the film as a metaphor for an oppressed woman constantly challenging the state which oppresses her. The depiction of the oppressive system which the prisoners must tolerate is spread across various periods intentionally. In the film, the depictions of the oppressive conditions to which women have been subjected include the periods immediately after the revolution, the Iran-Iraq war, and the reform period after Khatemi's presidency. Tahereh's power is limited by the very system she serves. As the years pass, her power is diminished under new political reforms taking place outside and inside of the prison, and the blind veil which has covered her eyes (and heart) for much of the film is lifted when she finally allows herself to give into the 'feminine subjective' during the scene in which she applies banned lipstick to her lips. Mitra is a glimmer of feminist hope in the film: even though she has been jailed for murdering her violent step-father and has been imprisoned for 17 years, she has not lost her self-respect, and she walks out of the prison with her head held high. The relationship between the two main characters is that of a love-hate dynamic filled with symbolism. Mitra is the free-spirited being whom Tahereh yearns to be. Once Mitra is freed, it is as if Tahereh's soul also becomes free.

\section{The Development of Freedom in Hush! Girls Don't Scream}

As we examine violence in the traditions and attitudes related to women in film, it is important to juxtapose the representations of this violence and oppression in Iranian society with the narratives that appear on screen. Based on an expanded notion of freedom, we move forward in identifying the inequality and transgression of gender-segregation norms represented in Pouran Derakhshande's controversial film, Hush! Girl's Don't Scream.

Islam's gender-related norms have often had brutal effects on women in Iran. The war on women has manifested itself in blatant gender-based discrimination including assaults on women, the tarnishing of the female image, and systematic inequality. Iranian women who demand equal rights are constantly faced with patriarchal post-revolutionary policies that permit violence against women, a situation that has become more pressing within the dichotomies that exist under Islamic law and state legislation and which have been reinforced to maintain power imbalances within Iranian society.

After the 1979 revolution, the Iranian government began distancing itself from the standard conceptualization of universal human rights ${ }^{11}$ to accommodate its own constitution and 
legislation based on revolutionary ideals rooted in anti-imperialism. While women initially took to the streets, protesting and wearing the chador as a sign of solidarity with Khomeini, mechanisms restricting the role of women in society were established.

The new regime discarded women who did not sympathize with the republic and employed its own gender- based agenda in the form of capitalist imperialism. Women's representation in public positions, including political and decision-making ones, has continuously been subject to restrictions. Under the state ideology of Iran, the economic, social, and legal representation of women exists within a hegemonic gender-based contract which has left women subject to unequal treatment. Therefore, regarding violence against the female subject in both domestic and other relationships, in some state-run institutions, women also face a serious threat to their safety.

'Moral crimes' provide the context for one of the most common examples of discrimination against women in Iran, with plain-clothes government agents patrolling the streets and arresting women, charging them with 'crimes' as minor as wearing inappropriate clothes. More serious crimes, including murder and political offenses against the government, are punished with the death penalty. One of the most famous cases of gender-based bias within the Iranian institutional context involved the imprisonment and execution of Reyhaneh Jabbari. Jabbari's case was widely followed by international agencies and provoked controversy, as she was sentenced to death for the murder of a former employee of the Iranian Ministry of Intelligence. Jabbari claimed she acted in self-defense after the victim tried to rape her, but her claim was dismissed by the court without a proper investigation. The family of the victim demanded the death penalty under qisas and wanted the execution to proceed. On October 25, 2014, Jabbari was abruptly executed, even though questions had been raised about due process and the court's failure to recognize her claim of self-defense, with protests to halt her execution ignored. Unfortunately, the implementation of the death penalty on moral grounds is common in Iran's legal system. Women's movements and groups, including activists and intellectuals, have not become discouraged by the government's purification efforts. Women have engaged in more fields of public discourse than ever and have continued their fight for equal rights within a patriarchal society.

In Hush! Girls Don't Scream, Derakhshande applies the gender-based conceptualization of power to the context of rape and abuse. The violent oppression that the female subject encounters in this film revolves around efforts to undermine women socially and psychologically. The phenomena of paedophilia and child abuse are portrayed brilliantly, as the director relates the story to the real-life issue of violence against women. In Iranian society and the film, women are encouraged to remain quiet about abuse and are taught from childhood to act 'morally' and avoid damaging their families' reputations. In a society dominated by Islamic law, women who have been abused are sometimes considered guilty of encouraging abuse by their male counterparts. Children are also discouraged from speaking up, with their families often dismissing their claims or choosing to ignore them completely. In the film, Shirin's attempt to protect a child who is being abused by the building's caretaker results in her own conviction under Islamic law, and she is sentenced to death after the abuser's brother dies 
from an accidental overdose, which leads to the subversion of qisas, as he is the only surviving family member. Shirin, who was abused as a child herself, is forced to recount the details of her abuse at the hands of her mother's employee, Murad. Shirin kept the abuse secret from her family and fiancé, allowing the psychological trauma to torment her throughout her life and hiding the fact that she was engaged twice before, attempted suicide, and was committed to a mental hospital from her fiancé, Ali, because of the potential repercussions.

Reputation is an important concept in Iranian society, and most women who have been abused hide their trauma from their families and friends due to the taboo against it. The distinction between 'male' and 'female' becomes apparent in the fact that women tend to be blamed for their trauma. Unfortunately, in Iran, early psychoanalytic theories are often accepted, with women being subjected to ideas of 'victim-precipitated rape' and psychoanalytic views that 'if a woman was raped, she must have "asked for it" (Donat \& D'Emilio, 1992). This view has been discredited in first-world countries; however, in societies governed by Islamic law, it is common for victims to be blamed for abuse and be left 'solely responsible for what becomes of the unfortunate event' (Amir, 1971).

What this film highlights is Iranian society's view of male dominance of women, using disgrace and dishonor as weapons against women and making it unlikely that they will report crime to the authorities. As Shirin finally recounts her own abuse after she kills the caretaker, a feminist perspective is advanced under sad circumstances. Men use women to gain power and appropriate women's power for their own benefit.

Social construction also plays a pivotal part in rape culture in Iran. The motive of a male rapist is the desire to exert his masculinity and express sexual entitlement by overpowering the female subject. The theory of social construction is supported within the patriarchal sphere of rape culture and suggests that cultural factors play a strong part in rape. The culturally dominant script in Iran holds that power relations are defined by masculine practice; thus, when a man feels powerless, he can compensate for his powerlessness by dominating the female subject through rape (Cossins, 2000).

Shirin's rapist is portrayed as a weak man who must submit to his boss (Shirin's mother); thus, he assaults a child, whom he knows has no strength or power, threatening to suffocate her if she does not keep quiet. Iran's social dynamic leaves many men without a sense of masculinity, driving them to compensate for their perceived weakness in any manner they can.

\section{Conclusion}

The evolution of feminist perspectives in Iranian Cinema has become very evident in the works of female directors and female activists, both documenting women as agents of gender inequality. The Iranian women's movement through the lens of the camera has now forged the socio-political aspects of life in Iran into campaigns and has disregarded the atmosphere of repression by protesting for women's empowerment and equal rights through the narrative of their movies. The films analyzed in this study address important socio-political issues that Iranian citizens, especially women, face on a day-to-day basis. By going against the grain, these 
narratives highlight women's issues that have led to political/social mobility and protest since the 2009 elections, creating a form of resistance cinema which abolishes psychoanalytic theories of feminism and establishes a progressive women's cinema which has the ability to threaten the patriarchal institution. Films such as Nargess, Woman's Prison and Hush! Girl's Don't Scream are weaponized in the fight for equality and justice amongst every suffering woman in Iran, and the rest of the world.

\section{Conflict of Interest}

The author of the article declares no conflict of interest.

\section{Funding}

This research study was not funded by any institution. The author conducted the study on her own expenses.

\section{References}

Araneta-de Leon, R. C. (2000). Makasalanan o kapus-palad: A phenomenological study of children in conflict with the law. Philippine Journal of Psychology, 33(1).

Apao, L., Dayagbil, F., \& Abao, E. (2014). Alternative learning system accreditation and equivalency (ALS A\&E) program: Quality of life beyond poverty. International Journal of Interdisciplinary Research and Innovations, 2(4), 20-26.

Atilano, E. B., Desipeda, C. J., Domingo, Z. J., Garbin, S. N., \& Omanito, R. A. (2016). Factors influencing the dropout rate in Alternative Learning System Accreditation and Equivalency Program. The Online Journal of New Horizons in Education, 6(4), 99-109.

Bhagat, R.(2015). Juvenile Justice in Asia Pacific within a Human Rights Framework: A Case Study of India. International Journal of Education and Social Science, Vol. No.7.

National Research Council. (2013). Reforming juvenile justice: A developmental approach. National Academies Press.

Braun, V., \& Clarke, V. (2006). Using thematic analysis in psychology. Qualitative research in psychology, 3(2), 77-101.

Leicht, A., Heiss, J., \& Byun, W. J. (2018). Issues and trends in education for sustainable development (Vol. 5). UNESCO Publishing.

Carr, E. C., \& Worth, A. (2001). The use of the telephone interview for research. NT research, 6(1), 511-524.

Chappell, D., \& Lincoln, R. (2007). Abandoning identity protection for juvenile offenders. Current Issues in Criminal Justice, 18(3), 481-487.

Cho, H. (2017). Navigating the meanings of social justice, teaching for social justice, and multicultural education. International Journal of Multicultural Education, 19(2), 119. 
Muñoz-Salazar, P., \& Acuña-Collado, V. (2016). Juvenile Offenders: Characteristics and Reasons Why They Drop Out of Regular Education, in Valparaiso Region. Universal Journal of Educational Research, 4(12), 2744-2749.

Underwood, L. A., Dailey, F. L., Merino, C., \& Crump, Y. (2015). Results from a MultiModal Program Evaluation of a Four Year Statewide Juvenile Sex Offender Treatment and Reentry Program. Journal of Prison Education and Reentry, 2(2), 1932.

De Lauretis, T. (1987). Technologies of gender: Essays on theory, film, and fiction. Indiana University Press.

Department of Education (2016). Press released. Isang Daan, Isang DepEd toward education for all from http://www.deped.gov.ph/press-releases/isang-daan-isang-deped-towardeducation-all

Department of Education (2016). Press released. Age Does Not Matter: DepEd 2017 Proposed Budget Seeks to Hasten ALS Expansion from http://www.deped.gov.ph/press-releases/age-does-not-matter-deped-2017-proposedbudget-seeks-hasten-als-expansion

DiMartino, J., \& Castaneda, A. (2007). Assessing applied skills. Educational Leadership, 64(7), 38-42.

Francisco, K. (2016). PNP: Quezon City has highest number of index crimes. Rappler. Retrieved, 19.

Guerro, C. S. (2006) Alternative Learning System. Teacher Induction Program. Department of Education. Module 2.2.

Jabbarifar, T. (2009, November). The importance of classroom assessment and evaluation in educational system. In Proceedings of the 2 nd International Conference of Teaching and Learning (pp. 1-9).

Johnson, S.M., Rosch, J. (2010) Juvenile or Adult Court: Research on Future Offending.

Center for Child and Family Policy, Duke University. pp. 21-24

King, R. M. (2000). Portfolio development: Using authentic learning assignments in psychology courses. North American Journal of Psychology, 2(1), 151-166.

Elebute, A., \& Shagaya, O. M. (2016). Impact of Vocational and Technical Education on Livelihood Sustenance and Economic Development in Nigeria: The Art Workshop Experience. International Journal of Vocational and Technical Education Research, 2(2), 15-35.

McDavid, J. W., \& McCandless, B. R. (1962). Psychological theory, research, and juvenile delinquency. J. Crim. L. Criminology \& Police Sci., 53, 1.

Mercado, I. P. (2015). Problems encountered in the alternative learning system in Tanauan City. International Journal of Education and Social Science, 6. 2(8), 38-43.

Moskalenko, M. R., Dorozhkin, E. M., Ozhiganova, M. V., Murzinova, Y. A., \& Syssa, D. O. (2016). Peculiarities of Students of Pedagogical Specialties Training in Preventive work with Juveniles Delinquents. International Journal of Environmental and Science Education, 11(16), 8810-8820.

Soriano Y.(2001) The Problem of Youth Offenders: When Children Commit Adult Crimes. Bulatla,t Issue no. 36 , p.21 - 27. 
Villaluz, Reynaldo D.(2008). Factors Affecting the Achievement of Completers in the Alternative Learning System Program in the Province of Laguna, Technological Institute of the Philippines, Manila, Dissertation.

Weiner, B. (2001). Intrapersonal and interpersonal theories of motivation from an attribution perspective. In Student motivation (pp. 17-30). Springer, Boston, MA.

Yang, S. (2015). Evaluation of the Intervention and Rehabilitation Program in Residential Facilities and Diversion Programs for Children in Conflict with the Law. Universalia, 245 Victoria Ave. Quebec, Canada. www.universalia.com 